\title{
ANALYSIS OF SHIP'S SAFETY IMPROVEMENT IN CONFINED WATERS WITH USE OF THE DECISION SUPPORT SYSTEM BASED ON EXPERT MANOEUVRES
}

\section{ANALIZA ZWIĘKSZENIA BEZPIECZEŃSTWA STATKU NA AKWENIE OGRANICZONYM PRZY ZASTOSOWANIU SYSTEMU WSPOMAGANIA DECYZJI OPARTEGO NA MANEWRACH EKSPERTÓW}

\author{
Pawel Zalewski \\ Maritime University of Szczecin, Faculty of Navigation \\ Akademia Morska w Szczecinie, Wydział Nawigacyjny \\ 70-500 Szczecin, ul. Wały Chrobrego 1-2 \\ e-mail: p.zalewski@am.szczecin.pl
}

\begin{abstract}
The paper presents analysis of possible ship's safety improvement in confined waters with the use of an expert system for navigator's decision support, constructed on the grounds of the knowledge base of gathered manoeuvres for a given type of ship, loading and hydrometeorological condition. The system generates results of encountered decision problems in the form of information about proposed adjustments of main engine, helm and tugs controls and future trajectory presented by means of panoramic graphic interface equivalent to vector large scale ENC and text interface of commands.
\end{abstract}

Keywords: decision-making process, knowledge acquisition, ship's motion model, simulation, navigation safety analysis.

Streszczenie: W artykule przedstawiono analizę możliwości zwiększenia bezpieczeństwa statku na akwenie ograniczonym stosując ekspertowy system wspomagania nawigacyjnego zbudowany na podstawie bazy wiedzy zebranych manewrów dla danego typu statku w określonym stanie załadowania i warunkach hydrometeorologicznych. System generuje wyniki rozwiązań problemów decyzyjnych $\mathrm{w}$ formie informacji o proponowanej nastawie maszyny głównej i steru, kącie i nastawie uciagu liny holowniczej oraz przyszłej trajektorii. Wyniki prezentowane są przy pomocy panoramicznego interfejsu graficznego odpowiadającego mapie wektorowej o dużej skali oraz interfejsu tekstowego komend.

Slowa kluczowe: proces decyzyjny, pozyskiwanie wiedzy, model ruchu statku, symulacja, analiza bezpieczeństwa żeglugi. 


\section{ANALYSIS OF SHIP'S SAFETY IMPROVEMENT IN CONFINED WATERS WITH USE OF THE DECISION SUPPORT SYSTEM BASED ON EXPERT MANOEUVRES}

\section{Introduction}

Simulation studies give perfect opportunity to record the expert knowledge of pilots commanding vessels in the relevant area. An essential problem of the acquisition and representation of navigator's knowledge referring the conduct rules (procedural knowledge) and the analysis and evaluation of navigational situation (declarative knowledge) can be solved by gaining knowledge directly from electronic records made during such research. This approach to the knowledge database creation has been described in detail in [4]. Creation of a decision support system based on such knowledge can lead to safer manoeuvring and ship's safety improvement in confined waters.

\section{Decision support system based on expert manoeuvres.}

During the discussed studies logged ship's passage parameters (or facts in expert systems' nomenclature) included (stored in the form of time matrix files with $1 \mathrm{~s}$ or $2 \mathrm{~s}$ intervals) (fig. 1):

- adjustments of ship's internal and external controls (main engine, helm, bow tug pull, bow tug line bearing, aft tug pull, aft tug line bearing, side tugs push forces in 6 predefined locations around the hull: bow, amidships and aft on port and starboard side), which actually were the expert decisions,

- ship's state vector parameters such as: waterline's gravity centre position: $\mathrm{P}_{\mathrm{xy}}(\mathrm{x}[\mathrm{m}], \mathrm{y}[\mathrm{m}]$ given in Universal Transverse Mercator 2D projection), longitudinal velocity over ground (along the heading line): $\mathrm{v}_{\mathrm{x}}[\mathrm{kn}]$, transverse velocity over ground: $\mathrm{v}_{\mathrm{y}}[\mathrm{kn}]$, angular velocity over ground: $\omega\left[{ }^{\circ} / \mathrm{s}\right]$ and ship's heading: $\psi\left[^{\circ}\right]$.

The information gained from these records could be classified according to [1] to the information necessary for safe execution of an intended manoeuvre regarding:

1) information on the water area referring to safe depth contours,

2) information on the ship's waterline positions in the area. 


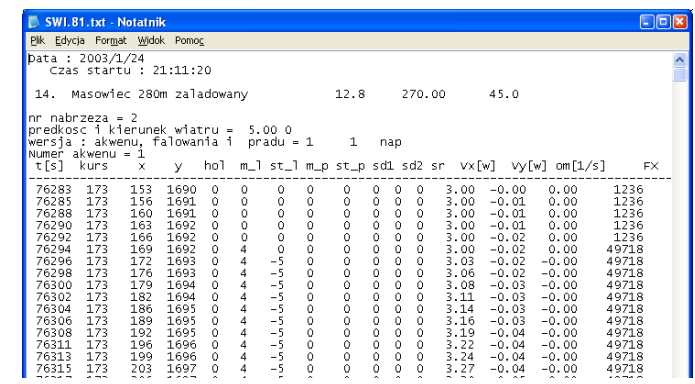

Fig. 1. Exemplary file of the recorded expert passage.

In order to acquire expert decisions most relevant for current ship's situation the expert passage most close in the aspect of registered state vector parameters has to be found. This way the risk of wrong decision should be minimised. So, the problem should be reduced to finding the minimum difference between current ship's state vector and ship's state vector recorded in the files of expert passages. The resultant target function for the optimisation of a planned manoeuvre in the given navigation conditions will be the function of the mentioned differences between both ship's state vectors' parameters:

$$
u=f\left(\Delta P_{x y}, \Delta v_{x}, \Delta v_{y}, \Delta \omega, \Delta \psi\right) \rightarrow \min
$$

where:

$\Delta P_{x y}$ - difference between waterlines' positions [m], $\Delta v_{x}$ - difference between waterlines' longitudinal velocities [kts], $\Delta v_{y}$ - difference between waterlines' transverse velocities [kts], $\Delta \omega$ - difference between waterlines' angular velocities [\% $\%$ ], $\Delta \psi$ - difference between waterlines' headings [ $\left.{ }^{\circ}\right]$.

The following assumptions have been taken into account while defining the final form of this function:

a) the examined ship is manoeuvring in restricted area, where its accurate position is defined in the Cartesian coordinate system,

b) the examined area is also presented in the Cartesian coordinate system, where the coordinates: $x \in X, y \in Y$,

c) ships allowed to manoeuvre in the examined area belong to the countable, finished set $J$ (this applies to size, type and loading conditions of vessels and other technical aspects affecting their manoeuvring characteristics), 
d) characteristic navigational (hydrometeorological) conditions are contained in the countable, finished set $K$,

e) ship's state vector parameters are analysed in two dimensions only (three degrees of freedom), in the accepted coordinate system,

f) parameters of ship's state vectors' differences are normalized in some established ranges to the non dimensional values from the range of $0 \ldots 1$.

Accepting the above assumptions the target function (1) can take the following form:

$$
u_{j k}=\sum_{i+1}^{5} \Delta_{N j k} p_{i} \rightarrow \min
$$

where:

$j \in J, k \in K$;

$$
\Delta_{N j k} p_{i}=n_{i} \times \Delta\left(p_{C j k i}, p_{E j k i}\right)
$$

$\Delta_{N j k} p_{i}$ - normalized absolute non dimensional difference between current ship's state vector $i^{\text {th }}$ parameter and consecutively registered during expert passages $i^{\text {th }}$ parameter of $j^{\text {th }}$ ship type in $k^{\text {th }}$ navigational conditions,

$p_{C j k i}-i^{\text {th }}$ parameter of the current ship's state vector,

$p_{E j k i}-i^{\text {th }}$ parameter of the registered expert ship's state vector,

$n_{i} \quad$ - normalization constant for $i^{\text {th }}$ type of ship's state vector parameter:

$n_{1}$ - normalization constant for distance between waterline's present and expert position $[1 / \mathrm{m}]$ :

$$
\Delta_{N j k} p_{1}=\Delta_{N j k} P_{x y}=n_{1} \sqrt{\left(x_{E}-x_{C}\right)^{2}+\left(y_{E}-y_{C}\right)^{2}}
$$

where: $\left(x_{E}, y_{E}\right)$ - Cartesian position gained from expert passage,

$\left(x_{C}, y_{C}\right)$ - present position,

$n_{2}$ - normalization constant for difference between longitudinal velocities $[1 / \mathrm{kts}]$ :

$$
\Delta_{N j k} p_{2}=\Delta_{N j k} v_{x}=n_{2}\left|v_{E x}-v_{C x}\right|
$$

$n_{3}$ - normalization constant for difference between transverse velocities $[1 / \mathrm{kts}]$ :

$$
\Delta_{N j k} p_{3}=\Delta_{N j k} v_{y}=n_{3}\left|v_{E y}-v_{C y}\right|
$$


$n_{4}$ - normalization constant for difference between angular velocities $\left[\mathrm{s} /{ }^{\circ}\right]$ :

$$
\Delta_{N j k} p_{4}=\Delta_{N j k} \omega=n_{4}\left|\omega_{E}-\omega_{C}\right|
$$

$n_{5}$-normalization constant for difference between waterline's headings $\left[1{ }^{\circ}\right]$ :

$$
\begin{aligned}
& \Delta \psi=\left|\psi_{E}-\psi_{C}\right|, \\
& \Delta \psi>180^{\circ} \Rightarrow \Delta \psi=360^{\circ}-\left|\psi_{E}-\psi_{C}\right| \\
& \Delta_{N j k} p_{5}=\Delta_{N j k} \psi=n_{5} \Delta \psi
\end{aligned}
$$

where: $\psi_{E}$ - heading gained from expert passage,

$\psi_{C^{-}}$present heading.

On the basis of the presented target function the decision tree for the expert system has been created and algorithm implemented in Delphi ${ }^{\mathrm{TM}}$ environment [4]. The results of this system work are expert decisions regarding ship's controls adjustments corresponding most closely to the current vector state. These decisions are presented in the form of matrix (or table) with commands in standard marine vocabulary for 3 consecutive manoeuvres taken previously by expert pilot. In the first column the elapsed time between adjustments' alteration is given. The discreteness of $0.1 \mathrm{~min}$ has been adopted as a value which gives navigator enough time for reaction and not impeding navigational safety. The adjustments (or commands) at this stage of system development has been restricted to main engine (propeller), helm, bow, aft and side tugs. The red colour warns navigator of the adjustment which should be changed according to expert's decision. The number of consecutive manoeuvres has been accepted according to the presentation clarity and expert navigators suggestions and can be changed if necessary (fig. 2).
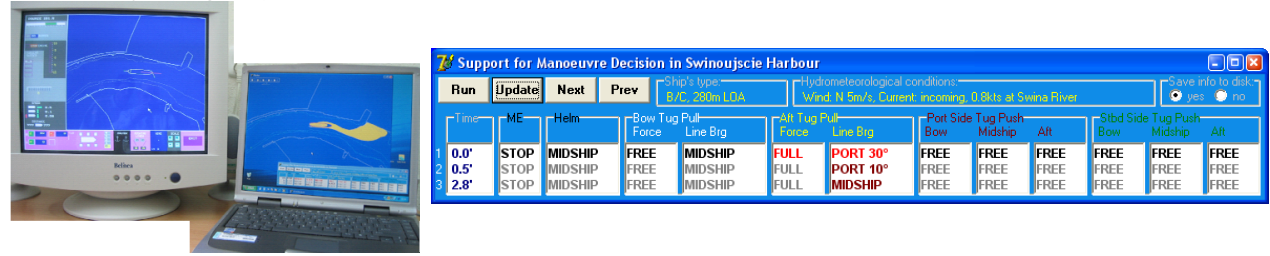

Fig. 2. Interface of the expert system with three consecutive expert manoeuvre decisions presented (adjustments of controls).

The extra help regarding manoeuvre decision is given by additional plotter interface (equivalent of electronic navigation chart presentation) which shows navigator future positions of ship's waterline as registered in the chosen expert passage in relation to ship's current waterline position. 
System's verification has been performed by means of simulation trials, where a current ship's state vector has been randomly chosen from one registered passage and expert ship's state vectors form the other expert passages.

After several simulation trials with different numbers of expert passages included, the values of normalization constants have been accepted as presented in [4].

\section{Analysis of navigational safety improvement.}

Main criterion of navigational safety analysis is meeting the goal of inclusion of manoeuvring area within the safe area.

Measuring of the ship's manoeuvring area consists of the determination of its horizontal parameters in each point $(x, y)$, at the very moment $(t)$ of the manoeuvring in progress (fig. 3) [2]. The manoeuvring area will be safe if additionally the condition of safe depth is met:

$$
h(x, y, t) \geq T(x, y, t)+\Delta_{T}(x, y, t)
$$

where:

$h(x, y, t) \quad$ - $\quad$ set of charted depths assuming no tides,

$T(x, y, t) \quad$ - $\quad$ set of ship's draughts,

$\Delta \mathrm{T}(x, y, t)-\quad$ set of under-keel clearances.

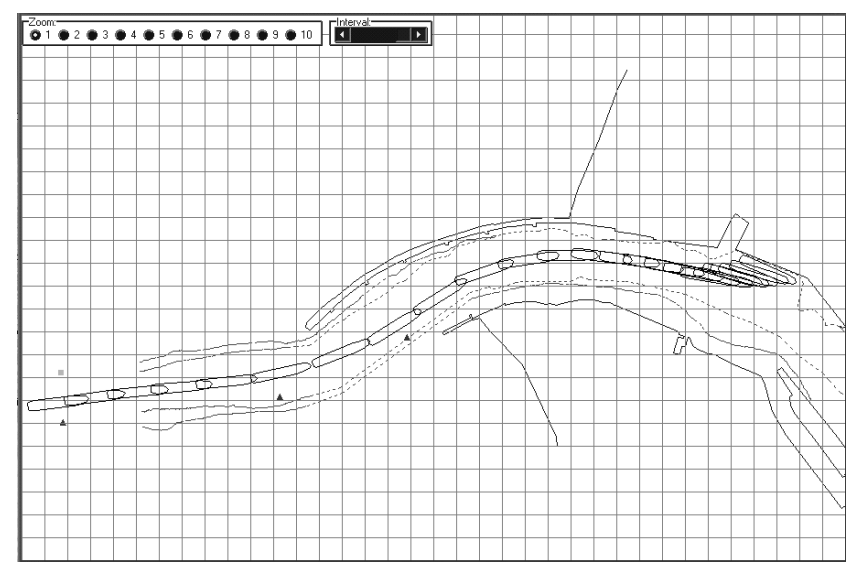

Fig. 3. Graphical presentation of data logged during ship manoeuvring - ship's path from one passage.

The reckoning of random variables of maximum distances between extreme points of the assumed ships' hull waterline outline and the reference line, for example: a fairway axis, leads to determination of the manoeuvring water 
area width. The manoeuvring water area width at a specified confidence level can finally lead to comparison with the existing safe area width and to conclusions of navigational safety within this area. The navigational safety can also be expressed in terms of the probability of accident because manoeuvring area dimensions always meet the safe area dimensions at some confidence level equal to one minus value of the probability of accident:

a) without considering accident consequences, the confidence level usually must be equal or higher than 0.95 ;

b) taking into account accident consequences the confidence level must be equal or higher then confidence level calculated from the value of the probability of accident at fixed acceptable accident risk level.

To analyse data logged in ship simulator an original Delphi ${ }^{\mathrm{TM}}$ application has been created. General algorithm is based on the methods of the ship's movement path and manoeuvring area determination described in $[2,3]$. To obtain the probability of an accident the probability function of assumed normal distribution (10) has been converted to a standard normal distribution by changing variables to: $Z \equiv(X-\mu) / \sigma$, so $d z=d x / \sigma$.

$$
\begin{aligned}
& P(x)=\frac{1}{\sigma \sqrt{2 \pi}} e^{-[x-\mu]^{2} /\left[2 \sigma^{2}\right]} \\
& P(x) d x=\frac{1}{\sqrt{2 \pi}} e^{-z^{2} / 2} d z .
\end{aligned}
$$

where:

$x$ - variable distance of logged extreme points of ship's hull outline to fairway axis,

$\mu-\quad$ mean of distances of logged extreme points of ship's hull outline to fairway axis,

$\sigma^{2}-$ variance of distances of logged extreme points of ship's hull outline to fairway axis.

The normal distribution function $\Phi(z)$ gives the probability that a standard normal variable assumes a value in the interval $[0, z](12)$.

$$
\Phi(z) \equiv \frac{1}{\sqrt{2 \pi}} \int_{0}^{z} e^{-x^{2} / 2} d x=\frac{1}{2} \operatorname{erf}\left(\frac{z}{\sqrt{2}}\right)
$$

where erf is so called error function which has been numerically computed by Maclaurin series approximation:

$$
\operatorname{erf}(z)=\frac{2}{\sqrt{\pi}} \sum_{n=0}^{\infty} \frac{(-1)^{n} z^{2+1}}{n !(2 n+1)}
$$


Because normal distribution function actually gives us confidence level for whole range of $x$ then for value $\mu$ (half of the $x$ range) it gives 0.5 . We are interested in confidence levels of values to one side of our $\mu$, and for $\mu$ that should be $100 \%$ (or 1.0 probability) accident. Finally probability of accident equals:

$$
P\left(x=d_{a}\right)=2(1-\Phi(z))
$$

where:

$d_{a}$ - distance from the fairway axis to the safety limit (isobath or obstacle).

According to the above procedure the simulation studies were performed with the samples of 20 captains and pilots (experts) and 30 post-engineer (MSc) students from Maritime University of Szczecin. Each expert and student was asked to perform one simulation passage into Świnoujście harbour on PC ship's manoeuvring simulator after previous familiarization with its interface. The data gathered from expert passages were treated as expert and built the knowledge base for the decision support system. The data gathered from students were treated as without decision support. After finishing this task the students were asked to perform simulation passages once more but this time with decision support system connected to the simulator. The results in the form of ship's paths statistical analysis are presented on fig. 4 and table 1.

Tab. 1. Ship's paths widths obtained from experts' passages, students' passages and students' passages supported by the decision system.

\begin{tabular}{|l|l|l|l|l|l|c|c|}
\hline $\begin{array}{r}\text { Reference axis } \\
\text { range [km] }\end{array}$ & 2.10 & 2.15 & 2.20 & 2.25 & 2.30 & $\begin{array}{c}\text { Average } \\
\text { path } \\
\text { width } \\
\text { [m] }\end{array}$ & $\begin{array}{c}\text { Average probability } \\
\text { of grounding to E } \\
\text { 14.5m isobath } \\
\text { (outer dashed line } \\
\text { on fig.4) }\end{array}$ \\
\hline $\begin{array}{l}\text { 95\% ship's path } \\
\text { widths gained by } \\
\text { experts [m] }\end{array}$ & 127 & 127 & 128 & 122 & 123 & $\mathbf{1 2 5}$ & $\mathbf{0 . 0 0 0 0 0 9 0 6}$ \\
\hline $\begin{array}{l}\text { 95\% ship's path } \\
\text { widths without } \\
\text { decision support } \\
\text { system [m] }\end{array}$ & 151 & 150 & 149 & 149 & 146 & $\mathbf{1 4 9}$ & $\mathbf{0 . 0 0 0 7 8 9 4 3}$ \\
\hline $\begin{array}{l}\text { 95\% ship's path } \\
\text { widths with } \\
\text { decision support } \\
\text { system used [m] }\end{array}$ & 126 & 125 & 125 & 120 & 115 & $\mathbf{1 2 2}$ & $\mathbf{0 . 0 0 0 0 0 8 8 5}$ \\
\hline
\end{tabular}




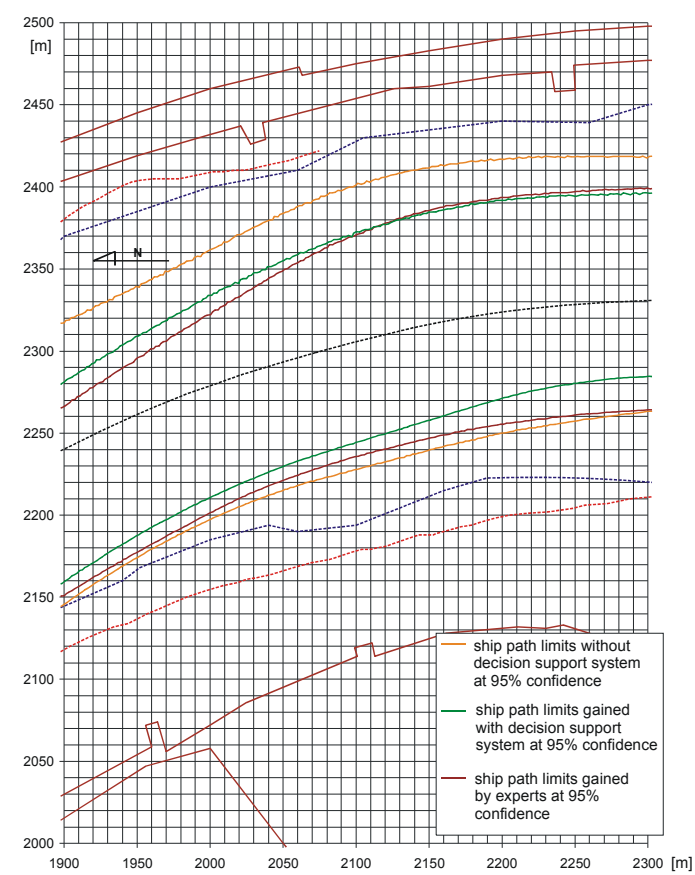

Fig. 4. Ship's paths widths obtained by students without decision support system, by students supported with the decision system and by experts.

\section{Conclusions}

The conclusion from the fig. $4 \&$ table 1 is straightforward. The students have been able to achieve much better manoeuvring tactics with decision support system suggesting consecutive expert manoeuvres. They've managed to avoid many wrong or too much time-delayed decisions commanding vessels in strict accordance to the procedure repeated in most of the expert passages.

The main advantage and strength of the presented decision support system lies in its simplicity and its flexibility. The computing power of contemporary workstations allow for data retrieval from vast number of files and very big matrixes, so its possible to collect almost all possible variants of manoeuvres in the form of series of expert passages in the area of interest, even on a standard PC. The resultant information, displayed on the system interface, is optimised in its scope as it is restricted only to the value of control adjustment and the moment of time it should be performed or activated. The main problem may be lying here in accuracy of the adopted simulation model of ship's motion if the knowledge base is extracted entirely from a simulated research. There are two possible solutions of this 
problem in the presented support system model. The first is a continuous verification of the adopted ship's model leading to higher and higher accuracy and the second is a possibility to accommodate real study data as well. It is presumed that by combining these methods the acceptable safety level will be achieved, but it still requires further research. Anyway one must remember that the presented system will be reliable only for hydrometeorological conditions and ship's types equivalent to the recorded sample.

The system which evolved on the presented assumptions, even taking no account of its decision support qualities, appeared to be very useful from the educational point of view especially in terms of students' familiarization with manoeuvring tactics of big vessels.

\section{References}

1. Gucma S.: Information system of ship pilotage support in restricted areas, KONBiN'03 - The 3rd Safety and Reliability International Conference Proceedings, ITWL, Warszawa 2003

2. Gucma S., Inżynieria Ruchu Morskiego, Okrętownictwo i Żegluga, Gdańsk, 2001.

3. Zalewski P.: Analysis of navigational safety by means of simulation studies in the Marine Traffic Engineering Centre in Szczecin, Proceedings of the International Conference on Marine Traffic Engineering 2007, Wyd. AM w Szczecinie, 2007.

4. Zalewski P.: Construction of the knowledge base for an expert system supporting navigator's manoeuvre decision in confined waters. Proceedings of the 9th IEEE International Conference on "Methods and models in Automation and Robotics" MMAR 2003, Wyd. Uczelniane Politechniki Szczecińskiej, Szczecin 2003, pp. 195-200 


\section{ANALIZA ZWIĘKSZENIA BEZPIECZEŃSTWA \\ STATKU NA AKWENIE OGRANICZONYM PRZY \\ ZASTOSOWANIU SYSTEMU WSPOMAGANIA DECYZJI OPARTEGO NA MANEWRACH EKSPERTÓW}

\section{Wstęp}

Badania symulacyjne umożliwiają kompleksową rejestrację wiedzy eksperckiej pilotów dowodzących statkami na badanym akwenie. Główny problem pozyskania i prezentacji wiedzy nawigatora dotyczącej zasad manewrowania (wiedza proceduralna) oraz analizy i oceny sytuacji nawigacyjnej (wiedza deklaratywna) może być rozwiązany w wyniku pozyskiwania wiedzy bezpośrednio $\mathrm{z}$ zapisów elektronicznych prowadzonych w trakcie takich badań. Taki sposób tworzenia bazy wiedzy został szczegółowo opisany w [4]. Budowa systemu wspomagania decyzji opartego na tej wiedzy może prowadzić do zwiększenia bezpieczeństwa manewrów i statku na akwenie ograniczonym.

\section{System wspomagania decyzji oparty na manewrach ekspertów}

W trakcie przeprowadzonych badań symulacyjnych rejestrowane były w plikach tablicowych, indeksowanych czasowo, co 1s lub 2s, następujące parametry (lub fakty w terminologii systemów ekspertowych) (rys. 1):

- nastawy wewnętrznych i zewnętrznych urządzeń manewrowych (silnika głównego, steru, nastawy maszyny holownika dziobowego, kąta kursowego uciagu holownika dziobowego,, nastawy maszyny holownika rufowego, kąta kursowego uciągu holownika rufowego, nastawy holowników dopychających w 6 predefiniowanych pozycjach dookoła kadłuba: na dziobie, śródokręciu i rufie po lewej i prawej burcie), które faktycznie stanowiły decyzje eksperckie,

- parametry wektora stanu statku: pozycja odniesienia umownej wodnicy (anteny systemu pozycyjnego): $\mathrm{P}_{\mathrm{xy}}(\mathrm{x}[\mathrm{m}], \mathrm{y}[\mathrm{m}] \mathrm{w}$ odwzorowaniu Universal Transverse Mercator), prędkość wzdłużna nad dnem (składowa wektora prędkości wzdłuż linii kursu): $\mathrm{v}_{\mathrm{x}}[\mathrm{kn}]$, prędkość poprzeczna nad dnem: $\mathrm{v}_{\mathrm{y}}[\mathrm{kn}]$, prędkość kątowa nad dnem: $\omega\left[{ }^{\circ} / \mathrm{s}\right]$ oraz kurs statku: $\psi\left[{ }^{\circ}\right]$. 
Informacje uzyskane z tych zapisów mogą być zaklasyfikowane według [1] do informacji niezbędnych dla bezpiecznego wykonania zamierzonego manewru uwzględniając:

1) informację o dostępnym obszarze manewrowym wytyczonym przez „bezpieczne” izobaty,

2) informację o położeniach umownych wodnicy statku (obwiedni kadłuba) wewnątrz tego obszaru.

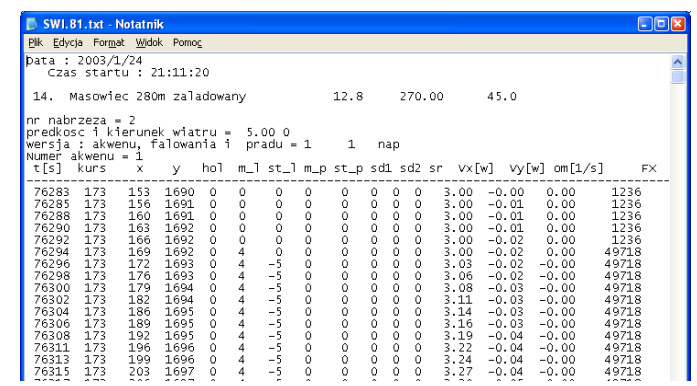

Rys. 1. Przykładowy plik z zarejestrowanym „,przejazdem” eksperckim.

W celu uzyskania decyzji eksperckich odpowiadających w największym stopniu bieżącej sytuacji nawigacyjnej należy znaleźć „przejazd” ekspercki najbardziej do niej zbliżony pod względem zarejestrowanych parametrów wektora stanu. Tym sposobem dla odpowiednio dużej liczebności zarejestrowanych „przejazdów” eksperckich ryzyko błędnej decyzji powinno być zminimalizowane. Problem można więc zredukować do znalezienia minimum różnicy pomiędzy bieżącym wektorem stanu statku a wektorem zarejestrowanym w plikach eksperckich. Wynikową funkcją celu optymalizacji planowanego manewru $\mathrm{w}$ danych warunkach nawigacyjnych będzie wobec powyższego funkcja różnic pomiędzy parametrami dwóch wektorów stanu statku:

$$
u=f\left(\Delta P_{x y}, \Delta v_{x}, \Delta v_{y}, \Delta \omega, \Delta \psi\right) \rightarrow \min
$$

gdzie:

$\Delta P_{x y}$ - różnica pomiędzy pozycjami odniesienia wodnicy [m],

$\Delta v_{x}$ - różnica chwilowych prędkości wzdłużnych [w],

$\Delta v_{y}$ - różnica chwilowych prędkości poprzecznych [w],

$\Delta \omega$ - różnica chwilowych prędkości kątowych [\% $/ \mathrm{s}]$,

$\Delta \psi$ - różnica kursów [ [ ${ }^{\circ}$.

Definiując finalną zależność funkcji celu przyjęto następujące założenia: 
g) badany statek manewruje na akwenie ograniczonym, a jego pozycja wyznaczana jest w kartezjańskim układzie współrzędnych (UTM),

h) badany akwen również zwymiarowany jest w kartezjańskim układzie współrzędnych: $x \in X, y \in Y$,

i) statki mogące manewrować na badanym akwenie należą do policzalnego skończonego zbioru $J$ (odnosi się to do wymiarów, typu i stanu ładunkowego statków oraz innych aspektów technicznych wpływających na charakterystyki manewrowe statków),

j) charakterystyczne warunki nawigacyjne (hydrometeorologiczne) należą do policzalnego, skończonego zbioru $K$,

k) parametry wektora stanu statku są analizowane tylko $\mathrm{w}$ dwóch wymiarach (trzy stopnie swobody), w przyjętym układzie współrzędnych,

1) parametry różnic pomiędzy wektorami stanu statku są znormalizowane w pewnych przyjętych zakresach do bezwymiarowych wartości w zakresie $0 . . .1$.

Przyjmując powyższe założenia funkcja celu (1) przyjmie następująca formulę:

$$
u_{j k}=\sum_{i+1}^{5} \Delta_{N j k} p_{i} \rightarrow \min
$$

gdzie:

$j \in J, k \in K$;

$$
\Delta_{N j k} p_{i}=n_{i} \times \Delta\left(p_{C j k i}, p_{E j k i}\right)
$$

$\Delta_{N j k} p_{i}$ - znormalizowana bezwymiarowa wartość absolutna różnicy pomiędzy aktualnym $i^{\text {-tym }}$ parametrem wektora stanu statku a zarejestrowanym w trakcie ,przejazdu” eksperckiego $i^{\text {-tym }}$ parametrem statku typu $j \mathrm{w} k^{-t y c h}$ warunkach nawigacyjnych,

$p_{C j k i}-i^{-t y}$ parametr aktualnego wektora stanu statku,

$p_{E j k i}-i^{-t y}$ parametr zarejestrowanego „eksperckiego" wektora stanu statku,

$n_{i} \quad$ - stała normalizacji dla $i^{\text {-tego }}$ typu parametru wektora stanu statku:

$n_{1}$ - stała normalizacji dla odległości pomiędzy obecną a ekspercką pozycją wodnicy $[1 / \mathrm{m}]$ :

$$
\Delta_{N j k} p_{1}=\Delta_{N j k} P_{x y}=n_{1} \sqrt{\left(x_{E}-x_{C}\right)^{2}+\left(y_{E}-y_{C}\right)^{2}}
$$

gdzie: $\left(x_{E}, y_{E}\right)$ - pozycja uzyskana z przejazdu eksperckiego, $\left(x_{C}, y_{C}\right)$ - pozycja aktualna,

$n_{2}$ - stała normalizacji dla różnicy pomiędzy prędkościami wzdłużnymi $[1 / \mathrm{w}]$ : 


$$
\Delta_{N j k} p_{2}=\Delta_{N j k} v_{x}=n_{2}\left|v_{E x}-v_{C x}\right|
$$

$n_{3}$ - stała normalizacji dla różnicy pomiędzy prędkościami poprzecznymi $[1 / \mathrm{w}]$ :

$$
\Delta_{N j k} p_{3}=\Delta_{N j k} v_{y}=n_{3}\left|v_{E y}-v_{C y}\right|
$$

$n_{4}$ - stała normalizacji dla różnicy pomiędzy prędkościami kątowymi $\left[\mathrm{s} /{ }^{\circ}\right]$ :

$$
\Delta_{N j k} p_{4}=\Delta_{N j k} \omega=n_{4}\left|\omega_{E}-\omega_{C}\right|
$$

$n_{5}$ - stała normalizacji dla różnicy pomiędzy kursami [1/ $\left.{ }^{\circ}\right]$ :

$$
\begin{aligned}
& \Delta \psi=\left|\psi_{E}-\psi_{C}\right| \text {, } \\
& \Delta \psi>180^{\circ} \Rightarrow \Delta \psi=360^{\circ}-\left|\psi_{E}-\psi_{C}\right| \\
& \Delta_{N j k} p_{5}=\Delta_{N j k} \psi=n_{5} \Delta \psi \\
& \text { gdzie: } \psi_{E} \text { - kurs uzyskany z przejazdu eksperckiego, } \\
& \psi_{C}-\text { kurs aktualny. }
\end{aligned}
$$

$\mathrm{Na}$ podstawie przedstawionej funkcji celu zbudowano drzewo decyzyjne systemu eksperckiego i zaimplementowano algorytm w środowisku Delphiт [4]. Rezultatem pracy tego systemu są decyzje eksperckie, dotyczące nastaw manewrowych statku, maksymalnie zbliżone do bieżącego wektora stanu. Te decyzje są prezentowane $\mathrm{w}$ formie tabeli komend w standardowym słownictwie morskim dla 3 kolejnych manewrów wykonanych poprzednio przez pilota - eksperta. W pierwszej kolumnie podawany jest upływający czas do zmiany nastawy - kolejnej komendy. Przyjęto dyskretyzację $0,1 \mathrm{~min}$., jako wartość dająca nawigatorowi wystarczająco dużo czasu na reakcję i niewpływającą na bezpieczeństwo nawigacji. Nastawy (lub komendy) na tym etapie budowy systemu zostały ograniczone do silnika głównego (śruby), steru oraz holowników (dziobowego, rufowego i burtowych - dopychających). Czerwony kolor ostrzega nawigatora o nastawie, która powinna być zmieniona zgodnie z decyzją ekspercką. Liczebność kolejnych manewrów została przyjęta biorąc pod uwage przejrzystość - czytelność wizualizacji oraz sugestie ekspertów i w razie potrzeby może zostać zwiększona (rys. 2).
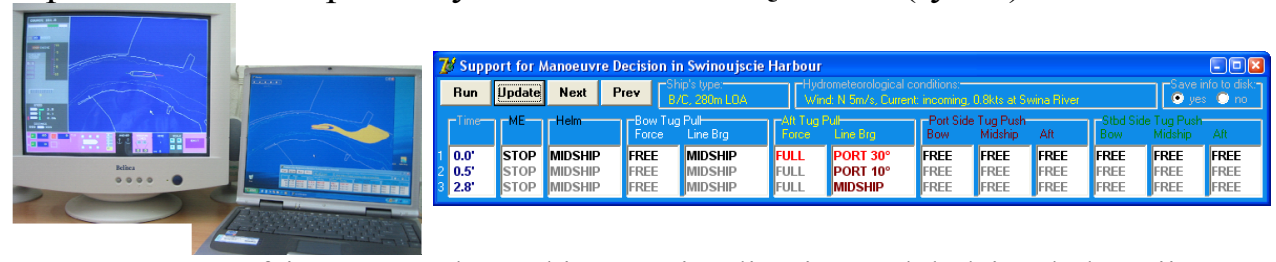

Rys. 2. Interfejs systemu eksperckiego z wizualizacją trzech kolejnych decyzji manewrowych ekspertów (nastawy urządzeń). 
Dodatkową pomoc dotyczącą decyzji manewrowej stanowi interfejs graficzny (odpowiadający zobrazowaniu mapy elektronicznej), który pokazuje nawigatorowi przyszłe położenia wodnicy statku $\mathrm{z}$ zarejestrowanego przejazdu eksperckiego $\mathrm{w}$ odniesieniu do bieżącego położenia wodnicy. Weryfikację systemu przeprowadzono za pomocą prób symulacyjnych, w których bieżący wektor stanu był losowo dobierany $\mathrm{z}$ jednego zarejestrowanego przejazdu a eksperckie wektory stanu z pozostałych zarejestrowanych przejazdów eksperckich. Po kilkudziesięciu próbach symulacyjnych o zmiennej liczebności przejazdów eksperckich przyjęto wartości stałych normalizacji opisane w [4].

\section{Analiza poprawy bezpieczeństwa nawigacji.}

Głównym kryterium bezpieczeństwa nawigacji jest zawarcie obszaru manewrowego statku wewnątrz bezpiecznego akwenu. Wymiarowanie obszaru manewrowego statku polega na określeniu jego parametrów $\mathrm{w}$ płaszczyźnie poziomej $(x, y)$, w każdym momencie czasu $(t)$ trwania manewru (rys. 3) [2]. Obszar manewrowy stanie się bezpiecznym, jeżeli dodatkowo będzie spełniony warunek bezpiecznej głębokości:

$$
h(x, y, t) \geq T(x, y, t)+\Delta_{T}(x, y, t)
$$

gdzie:

$h(x, y, t) \quad$ - zbiór głębokości (izobat) naniesionych na mapę nawigacyjną przy założeniu braku pływów,

$T(x, y, t) \quad$ - zbiór zanurzeń statku,

$\Delta \mathrm{T}(x, y, t)$ - $\quad$ zbiór rezerw wody pod stępką.

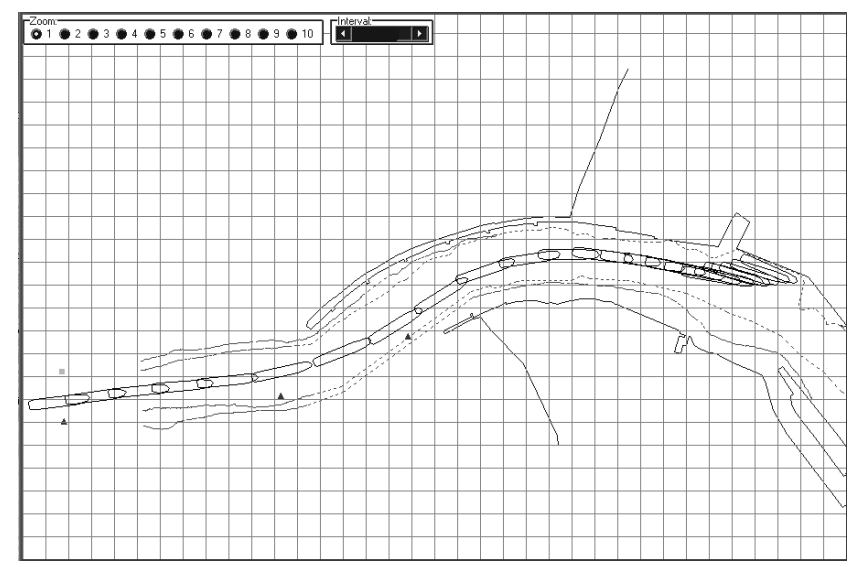

Rys. 3. Graficzna prezentacja danych zarejestrowanych podczas manewrowania statkiem trajektoria - pas ruchu statku z jednego przejazdu. 
Wyznaczenie zmiennych losowych maksymalnych odległości pomiędzy skrajnymi punktami umownej wodnicy statku a linią odniesienia, np.: osią toru wodnego, prowadzi do ustalenia szerokości obszaru manewrowego. Szerokość obszaru manewrowego na określonym poziomie ufności ostatecznie prowadzi do porównania $\mathrm{z}$ szerokością istniejącego dostępnego akwenu żeglownego i do oceny bezpieczeństwa nawigacji wewnątrz tego akwenu. Bezpieczeństwo nawigacji może być również wyrażone poprzez prawdopodobieństwo awarii - wypadku w trakcie wykonywania manewru, ponieważ wymiary obszaru manewrowego zawsze zrównają się z wymiarami bezpiecznego obszaru na pewnym poziomie ufności równym jeden minus wartość prawdopodobieństwa wypadku:

a) nie uwzględniając skutków awarii poziom ufności zwykle musi być równy lub większy od 0,95 ;

b) uwzględniając skutki awarii poziom ufności musi być równy lub większy od poziomu ufności wyznaczonego z wartości prawdopodobieństwa awarii na ustalonym poziomie ryzyka nawigacyjnego.

$\mathrm{W}$ celu analizy danych zarejestrowanych $\mathrm{w}$ symulatorze ruchu statku zaprojektowano autorską aplikację w Delphi ${ }^{\mathrm{TM}}$. Jej algorytm oparto na metodach wyznaczania pasa ruchu statku i obszaru manewrowego opisanych $\mathrm{w}[2,3]$. Aby otrzymać prawdopodobieństwo awarii funkcję gęstości prawdopodobieństwa przyjętego rozkładu normalnego (10) przekształcono na funkcję standardowego rozkładu normalnego zastępując zmienne: $Z \equiv(X-\mu) / \sigma$ oraz $d z=d x / \sigma$.

$$
\begin{aligned}
& P(x)=\frac{1}{\sigma \sqrt{2 \pi}} e^{-[x-\mu)^{2} /\left[2 \sigma^{2}\right]} \\
& P(x) d x=\frac{1}{\sqrt{2 \pi}} e^{-z^{2} / 2} d z .
\end{aligned}
$$

gdzie:

$x$ - zmienna losowa odległości rejestrowanych skrajnych punktów obwiedni statku od osi toru wodnego (osi odniesienia),

$\mu-\quad$ średnia odległości skrajnych punktów obwiedni statku od osi toru wodnego,

$\sigma^{2}-$ wariancja odległości skrajnych punktów obwiedni statku od osi toru wodnego.

Funkcja rozkładu normalnego $\Phi(z)$ daje prawdopodobieństwo osiagnięcia przez zmienną rozkładu normalnego standardowego wartości w przedziale $[0, z](12)$. 


$$
\Phi(z) \equiv \frac{1}{\sqrt{2 \pi}} \int_{0}^{z} e^{-x^{2} / 2} d x=\frac{1}{2} \operatorname{erf}\left(\frac{z}{\sqrt{2}}\right)
$$

gdzie erf jest tzw. funkcją błędu, którą można wyznaczyć numerycznie aproksymując ją w szereg Maclaurin'a:

$$
\operatorname{erf}(z)=\frac{2}{\sqrt{\pi}} \sum_{n=0}^{\infty} \frac{(-1)^{n} z^{2 n+1}}{n !(2 n+1)}
$$

Ponieważ funkcja gęstości rozkładu normalnego faktycznie wyznacza poziom ufności dla całego zakresu zmiennej losowej $x$ więc dla wartości $\mu$ (połowy zakresu zmiennej $x$ ) wyniesie ona 0,5 . Jesteśmy zainteresowani $\mathrm{w}$ poziomach ufności wartości z jednej strony $\mu$, a dla wartości równych $\mu$ poziom ufności powinien wynieść $100 \%$ (lub prawdopodobieństwo awarii $1,0)$. Wobec powyższego prawdopodobieństwo awarii wyznaczy zależność:

$$
P\left(x=d_{a}\right)=2(1-\Phi(z))
$$

gdzie:

$d_{a}$ - odległość od osi toru wodnego do granicy bezpieczeństwa (izobaty lub przeszkody).

Zgodnie z powyższą procedurą przeprowadzono badania symulacyjne na próbie 20 kapitanów i pilotów portowych (ekspertów) oraz 30 studentów studiów podyplomowych (magisterskich) z Akademii Morskiej w Szczecinie. Każdy ekspert i student był poproszony o wykonanie jednego symulacyjnego wpłynięcia do portu Świnoujście na symulatorze manewrowym PC po wcześniejszym zapoznaniu się z jego obsługą. Dane zebrane $\mathrm{z}$ przejazdów eksperckich zbudowały bazę danych wiedzy dla systemu wspomagania decyzji. Dane zebrane z przejazdów studenckich zostały potraktowane jako wykonane bez systemu wspomagania decyzji. Po zakończeniu tego zadania studenci zostali poproszeni o ponowne wykonanie przejazdów symulacyjnych, ale tym razem z podłączonym do symulatora opisanym systemem wspomagania decyzji. Wyniki $\mathrm{W}$ formie analizy statystycznej pasów ruchu statków są przedstawione na rys.. 4 i w tabeli 1 . 


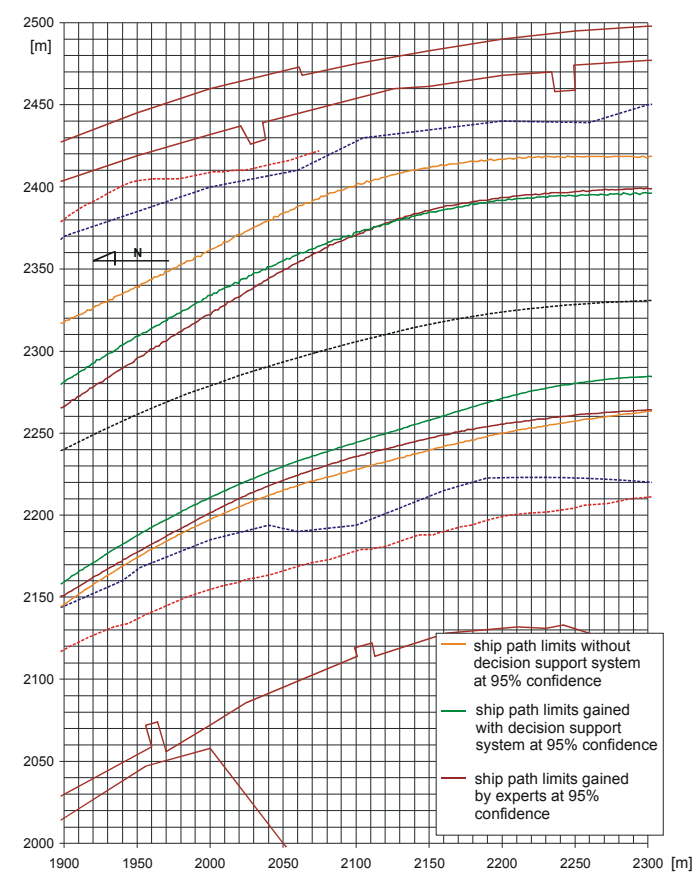

Fig. 4. Pasy ruchu statku uzyskane z przejazdów studenckich bez systemu wspomagania decyzji, z przejazdów studenckich z systemem wspomagania decyzji oraz z przejazdów eksperckich.

Tab. 1. Szerokości pasów ruchu statku uzyskanych z przejazdów studenckich bez systemu wspomagania decyzji, $\mathrm{z}$ przejazdów studenckich $\mathrm{z}$ systemem wspomagania decyzji oraz z przejazdów eksperckich.

\begin{tabular}{|l|l|l|l|l|l|c|c|}
\hline $\begin{array}{r}\text { Odcinek osi } \\
\text { odniesienia } \\
{[\mathrm{km}]}\end{array}$ & 2.10 & 2.15 & 2.20 & 2.25 & 2.30 & $\begin{array}{c}\text { Średnia } \\
\text { szer. } \\
\text { pasa } \\
{[\mathrm{m}]}\end{array}$ & $\begin{array}{c}\text { Średnie prawdopod. } \\
\text { wejścia na mieliznę } \\
\text { na izobacie E 14,5m } \\
\text { (zewnętrzna } \\
\text { kyp przejazdu }\end{array}$ \\
\hline $\begin{array}{l}\text { 95\% szer. pasa } \\
\text { ruchu uzyskane } \\
\text { przez expertów [m] }\end{array}$ & 127 & 127 & 128 & 122 & 123 & $\mathbf{1 2 5}$ & $\mathbf{0 . 0 0 0 0 0 9 0 6}$ \\
\hline $\begin{array}{l}\text { 95\% szer. pasa } \\
\text { ruchu bez systemu } \\
\text { wspomagania } \\
\text { decyzji [m] }\end{array}$ & 151 & 150 & 149 & 149 & 146 & $\mathbf{1 4 9}$ & $\mathbf{0 . 0 0 0 7 8 9 4 3}$ \\
\hline $\begin{array}{l}\text { 95\% szer. pasa } \\
\text { ruchu z systemem } \\
\text { wspomagania } \\
\text { decyzji [m] }\end{array}$ & 126 & 125 & 125 & 120 & 115 & $\mathbf{1 2 2}$ & $\mathbf{0 . 0 0 0 0 0 8 8 5}$ \\
\hline
\end{tabular}




\section{Podsumowanie}

Wnioski z rys. 4 i tabeli 1 są ewidentne. Studenci byli w stanie osiagnąć znacznie lepszy poziom taktyki manewrowej $\mathrm{z}$ systemem wspomagania decyzji sugerującym kolejne manewry eksperckie. Zdołali oni uniknąć wielu błędnych lub zbyt spóźnionych decyzji kierując statkami w ścisłej zgodzie z procedurą powtarzaną w większości przejazdów eksperckich.

Głównymi zaletami przedstawionego systemu wspomagania decyzji są prostota i elastyczność. Moce obliczeniowe współczesnych zestawów komputerowych pozwalają na odczyt danych z ogromnych ilości plików i bardzo dużych macierzy, czyniąc możliwym skolekcjonowanie prawie wszystkich wariantów manewrów na badanym akwenie $w$ formie zarejestrowanych przejazdów eksperckich, nawet na standardowym PC. Informacja wynikowa, wyświetlona na interfejsie systemu doradczego, jest zoptymalizowana $\mathrm{w}$ swoim zakresie, ponieważ ograniczono ją tylko do wartości zmiany nastawy i momentu czasu, w którym ta zmiana winna być dokonana. Problemem może być wierność przyjętego modelu symulacyjnego ruchu statku, w przypadku, gdy baza wiedzy pochodzi $\mathrm{W}$ całości $\mathrm{z}$ badań symulacyjnych. W przedstawionym systemie wspomagania decyzji istnieją dwa możliwe rozwiązania tego problemu. Pierwszym jest ciagła weryfikacja zastosowanego modelu matematycznego statku prowadząca do coraz wyższej wierności z rzeczywistością a drugim możliwość uwzględnienia danych z badań rzeczywistych. Można założyć, że kombinacja obu tych metod pozwoli osiagnąć akceptowalny poziom bezpieczeństwa, ale wymaga to dalszych badań.. W każdym razie należy pamiętać, że przedstawiony w referacie system będzie wiarygodny tylko dla warunków hydrometeorologicznych i typów statków odpowiadających zarejestrowanej próbie.

System, który rozwinięto przy wspomnianych założeniach i ograniczeniach, nawet nie biorąc pod uwagę jego zalet jako systemu doradczego, wydaje się być bardzo użytecznym $\mathrm{z}$ edukacyjnego punktu widzenia, szczególnie $\mathrm{w}$ celu zapoznania przyszłych nawigatorów $\mathrm{z}$ taktyką manewrowania dużymi statkami.

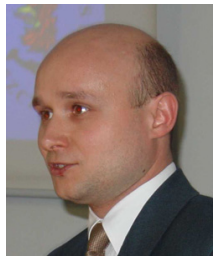

Dr. Eng., ZALEWSKI Pawel, Maritime University of Szczecin, Managing Director of Marine Traffic Engineering Centre in MUS, specialization: marine traffic engineering, safety of navigation, positioning systems, ship motion simulation, autonomous ship steering. More than 30 publications in the field. 
